\title{
Study of Flower Morphology, Pollen Viability, Germination and their Effect on Fruit Set in Different Cultivars of Litchi
}

\author{
Manish Kumar Jha* \\ Department of Horticulture (Fruit \& Fruit Technology), Bihar Agricultural College, \\ $B A U$, Sabour, Bhagalpur, Bihar, India \\ *Corresponding author
}

\section{Keywords}

Flowering, litchi, pollen morphology, pollen viability, sex ratio

Article Info

Accepted:

15 December 2019 Available Online: 20 January 2020

A B S T R A C T

Litchi (Litchi chinensis sonn) is the most important fruit of the Sapindaceae family. It originated in China and is widely distributed in the tropics and subtropics (Knight, 1980). Litchi is an important sub-tropical evergreen fruit crop. Therefore, the present investigation entitled "Study of flower morphology, pollen viability, germination and their effect on fruit set in different cultivars of litchi" was carried out during 2017-18 in the Department of Horticulture (Fruit and Fruit Technology), BAC, Sabour,. For this experiment four litchi cultivars viz.,Purbi, Bedana, Shahi and China were chosen for the present study. On the basis of data recorded on date of panicle it can be concluded that the litchi cultivar Purbi having the maximum number of duration of panicle initiation (25days) and cv. China having minimum number of duration of panicle initiation (18 days). The flowering characteristics like duration of flowering, and date of anthesis has been the maximum duration of flowering in cv. Purbi (18 days) and earlier anthesis was observed in cv. Bedana 05-03-2018 and whereas minimum duration was observed in cv. China (10 days) and late anthesis in China 22-03-2018. The panicle length differed significantly among the litchi cultivars. The data clearly indicated that among all the cultivars studied, Purbi produced the maximum panicle length $(43.80 \mathrm{~cm})$ which was at par with Shahi $(29.80 \mathrm{~cm})$, while the minimum panicle length was found in China $(27.20 \mathrm{~cm})$. The maximum panicle width was found significantly in Purbi $(34.40 \mathrm{~cm})$ followed by at par Shahi $(19.00 \mathrm{~cm})$, while the minimum width was observed in China $(14.00 \mathrm{~cm})$. It was observed that three types of flowers emerged in all the four cultivars of litchi i.e., $\mathbf{M}_{1}$ male, Functional female and pseudo-hermaphrodite flowers.

\section{Introduction}

The litchi (Litchi chinensis Sonn.) is the most important fruit of family, sapindaceae. The chromosome number is $2 \mathrm{n}=30$. Litchi is a subtropical fruit crop and is characterised by warm temperature. Litchi fruit is native of south China and grown in India since 
$18^{\text {th }}$ century. Litchi is currently growing in about 30 countries in tropical and subtropical regions of the world. China is the largest producer of litchi in the world and followed by India. Which is about one-fifth of the total global production and has a good export potential? In India area under litchi is 91000ha, which gives an yield or production of about 578000 MT under well managed condition (FAO). Of the total production of litchi in India, about $40 \%$ is contributed by Bihar. The average productivity of litchi in Bihar is 8.0 t/ha (NHB 2016-17). The major Litchi producer district in Bihar are Muzaffarpur, Bhagalpur, Darbhanga, Khagaria and Hazipur.

This crop is highly specified to a particular climatic condition and probably due to this reason its cultivation is restricted to few countries in the world. In India for Litchi cultivation the temperature varies from $21^{\circ} \mathrm{C}$ to $37.8^{\circ} \mathrm{C}$ during flowering to fruiting. Vegetative growth is inhibited and restricted by temperature below $10^{\circ} \mathrm{C}$ and above $35^{\circ} \mathrm{C}$ with maximum growth between $25-30^{\circ} \mathrm{C}$ depending on cultivars (Menzel et. al. 1989). It is however, sensitive to cold and the crop is severely injured by temperatures below freezing but can withstand light frosts. Relatively high rainfall of $1,200 \mathrm{~mm}$ per annum with high humidity is preferable (Tindall et al., 1994). A certain degree of water stress is needed for flower initiation. A dry climate, free from rains for about two months before flowering induce flower bud differentiation, blossom and consequently give high production (Cohen et al., 1992).

However, male $\left(\mathrm{M}_{1}\right.$ and $\left.\mathrm{M}_{2}\right)$ and female $(\mathrm{F})$ flowering stages may overlap on the same tree or between trees of the same cultivar, thereby providing an opportunity for self-pollination (Stern and Gazit, 2003). The results of pollination studies carried by Degani et al., (1995) indicated that pollen parent can have an effect on fruit-set, fruit retention and quality of litchi fruits. Length of the flowering cycle varies with the genotype and weather, and, is much shorter under warm temperatures. After flower initiation, development of flower panicle and flower continues uninterrupted and leads to anthesis, which lasts about 4 to 6 weeks depending on the temperature and the cultivar (Menzel, et al., 2001). Litchi flowering follows the pattern of "male-female-male". The ratio of male to female flowers varies with the environment and among its various cultivars. High temperature during flower initiation reduces the proportion of female flowers (Cronje, 2009).

In view of the above facts the work was carried out on commercial litchi cultivars grown in Bihar condition with following objectives:

\section{Materials and Methods}

The present investigation was carried out at the Horticultural Garden, Bihar Agricultural College, Sabour during the year 2017-2018 with a view "study of flower morphology, pollen viability, germination and their effect on fruit set in different cultivars of litchi". The details of materials used and experimentation adopted are discussed below:

The experiment was conducted in Horticulture Garden, Sabour, the permanent experimental site of the Bihar Agricultural College, Sabour, Bhagalpur. The experimental plot had well drained sandy loam soil of good fertility with levelled surface.

\section{Location and climatic conditions}

Bihar Agricultural College, Sabour is situated between $25^{\circ} 15^{\prime} 40^{\prime \prime}$ North longitudes of 45.72 meters above the mean sea level in the heart 
of the vast alluvial Gangetic plains of North India, South of River Ganga. The climate of Sabour is semi-arid, subtropical with hot desiccating summer, cold but frost less winter with an average annual rainfall of about 1150 $\mathrm{mm}$ precipitating mainly between middle of June to middle of October. Mainly three seasons influence the agricultural activities of this region, these are winter season (November to February), summer season (March to June) and rainy season (Mid June to October). Experimental Details

The experiment was conducted on uniform plants in respect of size, vigour and productivity of litchi hybrids and their parents in the orchard. The plants were 30 years old. All the trees received similar cultural practices and irrigation in the preceding years and during the experiment period. All details about materials used, experimental procedure followed and methods adopted for experiment are described below:-

Crop : Litchi

Number of treatments : 04

Number of replications: 05

Experimental design : Randomized block design

\section{Phenological observation}

\section{Date and duration of panicle initiation}

Date and duration of panicle initiation was recorded during the month of January and February with a regular visits in Horticultural Garden of BAC Sabour, the date of panicle emergence of four cultivars varied from 2301-2018 to 08-03-2018. Date of appearance of first panicle was recorded on the tagged shoots.

The observations were made to determine date of initiation of panicle.

\section{Length and width of panicle}

The length and width of panicle were measured with the help of a measuring scale from the shoot apex to that of panicle apex.

\section{Date of anthesis}

The date of anthesis of all four cultivars is recorded by regular visit and appearance of first flower was recorded on the tagged shoots. The observations were made to determine the date of anthesis after the panicle emergence.

\section{Duration of flowering}

The duration of flowering of all four cultivars is observed by counting the number of total days of flower retained in the panicle from date of anthesis to the date of initial fruit set.

Date and duration of emergence of $M_{1}$ (Male or staminate flower)

The date of emergence of Male flower is recorded by regular visit of field and duration was recorded from the interval in days from male flower emergence to emergence to Hermaphrodite flower.

\section{Date and duration of emergence of FF(Hermaphrodite female flower)}

The date of emergence of female flower (Hermaphrodite female flower) was recorded by regular visit to field and duration was recorded from number of days interval from emergence of female flower to pseudohermaphrodite flower.

Date and duration of emergence of $\mathrm{M}_{2}$ (Hermaphrodite male flower)

The date of emergence of $\mathrm{M}_{2}$ (Hermaphrodite male flower) was observed by regular visit to 
field and duration was recorded by numbers of days interval between emergence of $\mathrm{M}_{2}$ (Hermaphrodite male flower) and initial fruit set started.

\section{Number of male flowers}

Male flowers were counted on selected panicle and average number was expressed as number of male flowers per panicle. Observation on male flowers were recorded during middle of flowering season. Total numbers of flowers of above discussed kinds were counted in fully opened panicles with naked eyes and with the help of magnifying lens. In order to avoid error the counted flowers on panicles were removed and fresh open flowers were counted

\section{Number of female flowers}

Female flowers were counted on selected panicle and average number was expressed as number of female flowers per panicle. Observation on female flowers were recorded during middle of flowering season. Total numbers of flowers of above discussed kinds were counted in fully opened panicles with naked eyes and with the help of magnifying lens. In order to avoid error the counted flowers on panicles were removed and fresh open flowers were counted

\section{Number of Hermaphrodite flowers}

Hermaphrodite flowers were counted on selected panicle and average number was expressed as number of hermaphrodite flowers per panicle. Observation on hermaphridite flowers were recorded during middle of flowering season. Total numbers of flowers of above discussed kinds were counted in fully opened panicles with naked eyes and with the help of magnifying lens. In order to avoid error the counted flowers on panicles were removed and fresh open flowers were counted

\section{Percent of male flowers}

Percent of male flowers is calculated from this formula

$\%$ of male flowers $=$ -

Total number of flowers

\section{Percent of female flowers}

Percent of female flowers is calculated from this formula

No of female flowers

$\%$ of female flowers $=$ X 100

Total number of flowers

\section{Percent of hermaphrodite flowers}

Percent of hermaphrodite flowers is calculated from this formula

No. of hermaphrodite flower

$\%$ of hermaphrodite flowers =------------X 100

Total number of flowers

\section{Sex ratio}

Sex ratio of different cultivars is calculated by using this formula

$$
\text { Sex ratio }=\frac{\text { Total number of male flowers }}{\text { Total number of female flowers }}
$$

\section{To study the pollen viability}

\section{Date of anther collection and pollen viability}

The date of pollen collection was started during month of January and February in different flowers at different time period. Anthers were collected at dehiscence time between 8 and 10 a.m. by using forceps. After anther collection the pollen grains were distributed on the glass slide with the assistance of a brush and dyed with 1 or 2 drops of acetocarmine, thereafter left the slide for about 15-20 minutes for staining purpose. 
Then the pollen grains were observed under an optical microscope (compound microscope at $40 \times$ magnification) and the pollen grains which get fully stained got pink colour considered as viable pollen grains and which is not stained leave as transparent considered as non-viable pollen grains.

No. of viable pollen grains

Pollen viability $\%=$--------------X 100
Total no of pollen grains

\section{Pollen germination percentage}

In vitro Pollen germination in liquid medium

In vitro germination test in liquid media was done by hanging drop technique. The liquid germination medium containing $150 \mathrm{~g} / 1$ sucrose, $100 \mathrm{mg} / \mathrm{l} \mathrm{H}_{3} \mathrm{BO}_{3}, 1000 \mathrm{mg} / \mathrm{l}$ $\mathrm{Ca}\left(\mathrm{NO}_{3}\right)_{2}, 300 \mathrm{mg} / 1 \mathrm{MgSO}_{4}$ and $100 \mathrm{mg} / \mathrm{l}$ $\mathrm{KNO}_{3}$ at $\mathrm{pH} 5.5$ was prepared. Therefore, for in vitro germination, pollen grains were thoroughly mixed in $1000 \mathrm{ml}$ of liquid germination medium to get uniform pollen samples. Fifteen micro liter of this mixture was placed on a glass slide having $8 \mathrm{~mm}$ diameter ring inside. Slides were inverted and placed on a rack in a polycarbonate sealed container lined with moistened blotting paper and incubated in dark at $26^{\circ} \mathrm{C}$ temperature and observed them under optical microscope (compound microscope 40× magnifications).

No. of Germinated pollen grains Pollen germination \% = -------------- X 100

Total no of pollen grains

\section{In vitro Pollen germination on solid medium}

In vitro germination test was assessed in an agar solidifying medium containing $150 \mathrm{~g}$ /lsucrose, $100 \mathrm{mg} / 1 \mathrm{H}_{3} \mathrm{BO}_{3}, 300 \mathrm{mg} / 1$ $\mathrm{Ca}\left(\mathrm{NO}_{3}\right)_{2}, 200 \mathrm{mg} / \mathrm{l} \mathrm{MgSO} 4,100 \mathrm{mg} / 1 \mathrm{KNO}_{3}$ and $10 \mathrm{~g} / 1$ agar at $\mathrm{pH} 5.5$. After preparation of this solidifying media, pollen grains were dusted uniformly on the thin layer of growing medium taken on the separate slide and incubated for 24 hours in dark at $26^{\circ} \mathrm{C}$ temperature, and observed them under optical microscope (light microscope at 40x magnifications).

No. of Germinated pollen grains

Pollen germination \% = --------------- X 100

Total no of pollen grains

\section{Preparation of specimens for microscopic observation}

For this palynological investigation, the specimens were studied under light microscopy. The pollen samples for LM were acetolysed following the technique developed by Erdtman (1960) modified by Takahashi (1987). The anthers were soaked overnight in acetic acid for softening in $2 \mathrm{ml}$ polyethylene centrifuge tube and were crushed prior to acetolysis. The outmost care was taken to remove the debris and/or unwanted material e.g., fractions of floral parts or anther, filament, etc. The acetic acid acid was then decanted and acetolysis mixture $(9 \mathrm{ml}$ acetic anhydride: $1 \mathrm{ml}$ conc. sulphuric acid) was added to the centrifuge tube. The acetolysis took place at $100^{\circ} \mathrm{C}$ for $3-5 \mathrm{~min}$. A glass rod was inserted into each tube to stir the pollen sample within acetolysis mixture for the completion acetolysis process evenly. After acetolysis grains became yellow-brown to brown in colour. The acetolysed materials were washed with distilled water, dehydrated in ethanol series $(70 \%, 80 \%, 90 \%, 95 \%$, $99.5 \%$ and $100 \%$ ) and transferred in the benzene. A drop of silicon oil (viscosity 3000 cs.) was mixed with the material left in the benzene. The tube containing the material was left stand overnight at $75^{\circ} \mathrm{C}$ until the benzene had evaporated completely. The slides sealed with paraffin wax. At least four slides per 
specimens were made. All slides were investigated and photographed.

\section{To study the effect of pollen parameters on fruit set observation to be taken}

Crossing was conducted with the pollen from all these four varieties and Deshi and Purbi was taken as female parent for crossing purpose.

1. No. of flowers crossed

2. Number of fruit retained after 26 days of completion of fruit set.

The crossing is conducted by removing all the male flowers from those cultivars which is selected as female with the help of forceps and then dusting the pollen of four cultivars which is selected for study and then bagged the panicles for 10 days thereafter counting the initial fruit set and after 26 days recorded the fruit retained.

Number of Fruits per panicles Fruit retention $(\%)=$ X 100

Number of initial fruit set

\section{Results and Discussion}

A number of observations has been taken on flowering and fruiting characteristics like panicle characteristics, flowering behaviour and changes along with crossing effect and fruit set were recorded during the course of present investigation. In order to get complete picture of these parameters, the data collected were put to statistical analysis and their interpretation have been presented in this chapter. The results of the present investigation were elaborated in the preceding chapter. In this chapter scientific and logical interpretation of result obtained are discussed for clear and better understanding. Efforts have also been made to support the results with the previous findings.

\section{Panicle characteristics}

\section{Date and duration panicle initiation}

Panicle characters with respect to panicle initiation, length and width of panicle, varied significantly among the four cultivars. Purbi was the earliest to initiate panicle emergence i.e., 23-01-2018 followed by Shahi (08-022018) in Sabour condition. The variation observed in terms of panicle initiation might be due to the differences in genetic composition of different litchi genotypes as enunciated by various workers (Pathak et al., 2013; Das et al., 2004; Khurshid et al., 2004). The seasonal cyclic change of growth, flower, fruit and their development differ between genotypes and location. The process of panicle development is a genetically fixed property of the respective genotype or variety, but the environment of the growing site may cause significant changes in the manifestation of the inherited character. Other factors also play significant role in determining the rate of panicle development such as age, health and vigour of the tree (Das et al., 2002.

\section{Length and width of panicles}

Length and width of panicle was recorded to be the longest in Purbi $(43.80 \mathrm{~cm})$ whereas the shortest in China $(27.20 \mathrm{~cm})$. The variation in length and width of panicles might be due to genetic composition of litchi genotypes and more specifically the physiological condition of the shoot on which panicle is raised. Khurshid et al., (2004) had reported the maximum length and width of panicle in Gola cultivar of litchi while the minimum was recorded in Bedana.

\section{Flowering characteristics}

\section{Date and duration of flowering}

The initiation of flowering in different cultivars under study varied from 05-03-2018 
to 20-03-2018. The pattern and timing of floral initiation of litchi depends on genetic and environmental factors. Chauhan et al., (2014) reported that flowering commences in the second week of February in Uttrakhand.

The data showed that the maximum duration of flowering was recorded in Purbi (18 days) followed by China (10 days). This result is in accordance with finding of Pathak et al., (2013). He reported that total flowering duration in litchi varied between $13 \pm 4$ days in cv. China to $30 \pm 3$ days in cv. Piazi.

Numbers of Male (M1), female and Hermaphrodite (M2) flowers

In the present investigation the maximum number of male flowers was recorded in Purbi (646), which was found statistically at par with China (520). The significantly maximum number of female flowers was recorded in Purbi 311.00 followed by Bedana 221.00, while the minimum number of flowers was noticed in China i.e., 164.00. The significantly maximum number of hermaphrodite flowers was recorded in Purbi 587.00 followed by Shahi 546.00, while the minimum number of flowers was noticed in China i.e., 422.00.

\section{Sex-ratio}

Sex-ratio was significantly higher in China 3.17 followed by Bedana 2.84. The sex ratio is a variable component within panicles, trees and among genotypes. Sahay et al., (2005) reported that Bedana had significantly the maximum sex ratio followed by Late Bedana and Lal Bombai while the minimum was obtained in Ahjouli which was remained at par with China and Deshi. According to Pathak et al., (2013) sex ratio of flowers varied between 2.74:1 in cv. China and 5.8:1 in cv. Piazi. Similar observation was also recorded by Sarkar and Bandopadhyay (1989).

\section{Pollen viability and germination}

The pollen viability and germination percentage is maximum in cv. Purbi $(87 \%$, and $83.40 \%$ ) and minimum was observed in cv. China (78\%, and $74 \%)$. This might be due to genetic composition and environmental factor.

Amma and Kulkarni (1979) reported that for successful germination, pollen grains of different species require different growth component like water, sugar solution, inorganic salts, vitamins etc. at varying ranges and the composition and $\mathrm{pH}$ of the growth media are equally important factors for emergence of pollen tube from the grains on the media .

Robbertse et.al (1992) found that the obturator plays a vital role in the fertilization process of the litchi by facilitating the growth of pollen tubes around the broad base of the ovule towards the micropyle and embryo sac. Kozai et al., (2004). Previous studies on peach demonstrated that elevated temperatures during flower development can significantly reduce fruit set.

\section{Fruit set}

The date of fruit-set in different cultivars of litchi under study varied from 13-03-2018 to 25-03-2018. The maximum duration of fruit set was noticed in Purbi (9.8 days) followed by Shahi ( 8.26 days). The question of fruit set is of utmost importance in the production of any fruit crop. The variation observed in terms of fruit-set might be due to the differences in genetic composition of different litchi genotypes. Sharma and Roy (1987) reported that fruit se has occurred within 7-18 days of flowering. Mc Conchie and Batten (1991) suggested that the most appropriate time for fruit to be considered set is when most fruitlets on a panicle reach maturity. 
Table.1 The date and duration of panicles of four cultivars of litchi

\begin{tabular}{|l|c|c|c|c|}
\hline Cultivars & $\begin{array}{c}\text { Date of } \\
\text { panicle } \\
\text { Initiation }\end{array}$ & $\begin{array}{c}\text { Duration of } \\
\text { panicle } \\
\text { initiation (Days) }\end{array}$ & $\begin{array}{c}\text { Date of } \\
\text { anthesis }\end{array}$ & $\begin{array}{c}\text { Duration of } \\
\text { flowering } \\
\text { (Days) }\end{array}$ \\
\hline Purbi & $23-02-2018$ & 25 & $11-03-2018$ & 18 \\
\hline Bedana & $16-02-2018$ & 23 & $05-03-2018$ & 12 \\
\hline Shahi & $08-02-2018$ & 20 & $10-03-2018$ & 15 \\
\hline China & $08-03-2018$ & 18 & $22-03-2018$ & 10 \\
\hline
\end{tabular}

Table.2 The panicle length and width of four cultivars of litchi

\begin{tabular}{|l|c|c|}
\hline Cultivars & Length of panicle(cm) & Width of panicle(cm) \\
\hline Purbi & 43.80 & 34.40 \\
\hline Bedana & 30.60 & 19.00 \\
\hline Shahi & 29.80 & 17.00 \\
\hline China & 27.20 & 14.00 \\
\hline C.D at 5\% & $\mathbf{3 . 5 2}$ & $\mathbf{3 . 6 7}$ \\
\hline C.V & $\mathbf{7 . 7 0}$ & $\mathbf{1 2 . 1 2}$ \\
\hline
\end{tabular}

Table.3 The date of flower initiation of four cultivars of litchi.

\begin{tabular}{|l|c|c|c|}
\hline Cultivars & $\begin{array}{c}\text { Date of Male } \\
\text { flower initiation } \\
\left(\mathbf{M}_{\mathbf{1}}\right)\end{array}$ & $\begin{array}{c}\text { Date of female } \\
\text { flower initiation }\end{array}$ & $\begin{array}{c}\text { Date of pseudo- } \\
\text { hermaphrodite flower } \\
\text { initiation (M2) }\end{array}$ \\
\hline Purbi & $11-03-2018$ & $19-03-2018$ & $21-03-2018$ \\
\hline Bedana & $05-03-2018$ & $08-03-2018$ & $12-03-2018$ \\
\hline Shahi & $08-03-2018$ & $12-03-2018$ & $16-03-2018$ \\
\hline China & $20-03-2018$ & $25-03-2018$ & $28-03-2018$ \\
\hline
\end{tabular}

Table.4 The duration of flowering of four cultivars of litchi

\begin{tabular}{|l|c|c|c|c|}
\hline Cultivars & $\begin{array}{c}\text { Duration of male } \\
\text { flowering(Days) }\end{array}$ & $\begin{array}{c}\text { Duration of } \\
\text { female } \\
\text { flowering(Days) }\end{array}$ & $\begin{array}{c}\text { Duration of } \\
\text { pseudo- } \\
\text { Hermaphrodite } \\
\text { flowering(Days) }\end{array}$ & $\begin{array}{c}\text { Total no of } \\
\text { days }\end{array}$ \\
\hline Purbi & 4.0 & 6.2 & 6.0 & 16.20 \\
\hline Bedana & 3.8 & 5.5 & 5.2 & 14.50 \\
\hline Shahi & 3.6 & 5.2 & 4.2 & 13.00 \\
\hline China & 3.2 & 4.2 & 4.0 & 11.40 \\
\hline C.D at 5\% & $\mathbf{1 . 2 5}$ & $\mathbf{1 . 4 4}$ & $\mathbf{1 . 7 4}$ & $\mathbf{2 . 6 5}$ \\
\hline C.V & $\mathbf{5 . 5}$ & $\mathbf{5 . 6}$ & $\mathbf{5 . 8}$ & $\mathbf{6 . 5}$ \\
\hline
\end{tabular}


Table.5 The Numbers of flowers of four cultivars of litchi

\begin{tabular}{|l|c|c|c|c|}
\hline Cultivars & $\begin{array}{c}\text { No. of male } \\
\text { flowers }\left(\mathbf{M}_{\mathbf{1}}\right)\end{array}$ & $\begin{array}{c}\text { No. of female } \\
\text { flowers }(\mathbf{F F})\end{array}$ & $\begin{array}{c}\text { No. of pseudo- } \\
\text { Hermaphrodite } \\
\text { Flowers }\left(\mathbf{M}_{\mathbf{2}}\right)\end{array}$ & $\begin{array}{c}\text { Sex ratio } \\
\left(\mathbf{M}_{\mathbf{1}}+\mathbf{M}_{\mathbf{2}} \mathbf{\text { F }}\right)\end{array}$ \\
\hline Purbi & 646 & 311.8 & 587 & 3.95 \\
\hline Bedana & 629 & 221.0 & 558 & 5.37 \\
\hline China & 520 & 164.8 & 422 & 5.18 \\
\hline Shahi & 610 & 223.6 & 546 & 5.71 \\
\hline C.D at 5\% & $\mathbf{2 4 . 6}$ & $\mathbf{1 4 . 8 5}$ & $\mathbf{2 4 . 5 1}$ & $\mathbf{1 . 5 0}$ \\
\hline C.V & $\mathbf{2 . 9 3}$ & $\mathbf{4 . 6 2}$ & $\mathbf{3 . 3 3}$ & $\mathbf{1 2 . 4 8}$ \\
\hline
\end{tabular}

Table.6 Percentage of male flower, female flower and Pseudo-Hermaphrodite flower of different cultivars of litchi

\begin{tabular}{|l|c|c|c|}
\hline Cultivars & Male flower (\%) & Female flower (\%) & $\begin{array}{c}\text { Hermaphrodite } \\
\text { Flower (\%) }\end{array}$ \\
\hline Purbi & 41.83 & 20.14 & 38.00 \\
\hline Bedana & 44.67 & 15.69 & 39.63 \\
\hline Shahi & 44.25 & 16.17 & 39.59 \\
\hline China & 47.00 & 14.28 & 38.15 \\
\hline C.D at 5\% & $\mathbf{5 . 2 1}$ & $\mathbf{8 . 4 5}$ & $\mathbf{1 2 . 2 5}$ \\
\hline C.V & $\mathbf{1 . 5 3}$ & $\mathbf{2 . 3 6}$ & $\mathbf{3 . 2 6}$ \\
\hline
\end{tabular}

Table.7 Pollen viability and germination percentage of litchi cultivars

\begin{tabular}{|l|c|c|}
\hline Cultivars & Pollen viability (\%) & Pollen germination (\%) \\
\hline Purbi & 87.00 & 83.40 \\
\hline Bedana & 80.00 & 74.60 \\
\hline Shahi & 83.00 & 74.40 \\
\hline China & 78.00 & 74.60 \\
\hline C.D at 5\% & $\mathbf{5 . 2 9}$ & $\mathbf{4 . 5 3}$ \\
\hline C.V & $\mathbf{4 . 6 3}$ & $\mathbf{4 . 2 4}$ \\
\hline
\end{tabular}

\section{Effect of crossing method on fruit set}

Among the four cultivars, fruit set was recorded to be highest in case of Purbi $\mathrm{X}$ Bedana (20) followed in Desi X Bedana (17). There was poor fruit set by selfing. In contrary to this result Brijwal et al., (2016) had reported that initial fruit set under selfpollination was significantly higher than all crosses and open-pollination methods. Forneman et al., (2012) also reported the lower initial fruit set in all cross-pollination as compared to self-pollination in 'Wai Chee' litchi cultivar. Mc Conchie and Batten (1991) had suggested that the most appropriate time for fruit to be considered set is when most fruit left on a panicle reach maturity. 


\section{References}

Ali SB, Khan AA. (1998). Fruit Yield and Quality as Related to Flushes of Bearing Shoots in Litchi. J. Amer. Soc. Hort. Sci., 133(2):284-289.

Amma K. Kulkarni J. (1979). Studies on flowering biology, fruit set and its retention and quality of some litchi varieties. Ind. J. Hort., 26:124-129.

Banerji I, Chaudhari KL. (1944). A contribution to the life history of Litchi chinensis Sonn. Proceedings Indian Academy of Science, Section B:19-27.

Batten DJ. (1986). Maturity criteria for litchi (Lychee). Food Quality and Preference, 1:149-155.

Bhattacharjee S, Das BC, Hasan MA (2001) Studies on the morphology of fruit growth in litchi and their correlative relationship with fruit quality. Indian Agriculture.45:121-129.

Blanke MM, Lenz F. (1989). Fruit photosynthesis. Plant Cell Environment, 12:31-46.

Brahmachari VS, Kumar R, Verma, CK. (1997). Effect of foliar sprays of mineral nutrients on fruit set, retention and cracking of litchi (Litchi chinensis Sonn.) fruits. Haryana Journal of Horticultural Science 26 (3-4):80.

Brijwal M, Dimri DC, Mishra DS, Narayan A. (2016). Flowering and pollen morphological studies in some litchi (Litchi chinensis Sonn.) Journal of Biological Sciences, 17 (2): 283-290.

Chadha KL, Rajpoot MS. (1969). Studies on flowering biology, fruit set and its retention and quality of some litchi varieties. Indian Journal of Horticulture, 26:124-129.

Chandola JC, Mishra DS. (2015). Morphological and biochemical characterization of litchi cultivars. Indian Journal of Horticulture, 4(4): 361-365.
Chang JC. (2004). Studies on fruit set in 'No Mai Tsz' and 'Yu Her Pau' litchi. National Taiwan University, Taipei, Taiwan PhD Dissertation. (In Chinese with English summary).15:120-130

Chang JC, Tzong-Shyan, L.(2008) Fruit yield and quantity as related to flushing of bearing

shoots in litchi. Journal American Society Horticulture Science 133 (2): 284-289.

Chang JenYu, Chang Yu-An, Tang Lisa Chang Jer-Way. (2015). Characterization of generative development in early maturinglitchi 'Early Big', A novel cultivar in Taiwan Fruits, 70(5): 289-296

Chauhan S. (2015). Phenological studies in Litchi chinensis Sonn. (Sapindaceae). The International Journal of Plant Reproductive Biology 7(1): 88-90.

Cohen CB. Zuha D Moon, CD. (1992).Characterization of generative development in early maturing litchi. International Journal of Plant Reproductive Biology, 70: 289-296

Cronje RB, Shivakumar D. (2009). Effect of different preharvest treatment regimens on fruit quality of litchi cultivar 'Mauritius' Journal of PlantNutrition.32:19-29.

Dabral M. Misra KK. (2007). Studies on flowering and fruiting in some litchi cultivars. Indian Journal of Horticulture, 64(2): 207-210.

Das B, Dey P.(2004). Investigations on flushing and panicle emergence in litchi under sub-humid sub-tropical plateau region of eastern India. Indian Journal of Horticulture. 61(1):1-5

Das CS. and Roychoudhury KR. (1958). Floral biology of litchi (Litchi chinensis Sonn.). South Indian Horticulture, 6:1722

Das B. Suraja AK. Jinda C. (2002). Flowering and fruit set in lychee (Litchi chinensis Sonn.) Agricultural Reviews, 23(1): 59- 
64.

Dag R.D. Chand KR. Kumar RJ. (1999). Floral biology of litchi (Litchi chinensis Sonn.). South Indian Horticulture, 6:1722.

Datt R. (1998) Effect of growth regulators in fruit drop, fruit cracking and shelf life oflitchi fruits (Litchi chinensis Sonn.). M. Sc. Ag. (Horticulture), G.B. PantUniversity of Agriculture \& Technology, Pantnagar.

Degani C.Stern RA. Son, AJ. (1995). Pollen parent effect on the selective abscission of Mauritius and Floridian lychee fruits. Journal American Society Horticulture Science, 120: 523-26.

Gul SV Ahmed CV. (1989). Litchi Cultivation (in Spanish) (Menini, U.G., FAO Coordinator). FAO Plant Production and Protection Paper No. (83) FAO, Rome, Italy.

Gupta SP. Koul A. (2000). Floral biology of litchi (Litchi chinensis Sonn.). Haryana Journal of Horticultural Sciences 29(3/4): 143-144.

Hieke S. Menzel CM. Ludders P. (2002). Shoot development, chlorophyll, gas exchange and carbohydrate in litchi seedlings (Litchi chinensis Sonn.). Tree Physiology, 22:947-953.

Huang $\mathrm{H}$ and $\mathrm{Xu}$. (1983). The developmental patterns of fruit tissues and their correlative relationships in Litchi chinensis Sonn. Scientia Horticulturae 19: 335-342.

Kozai SD. Senz RP. and Raid SK. (2004). Flowering and fruit set in lychee (Litchi chinensis Sonn.) in subtropical Queensland, Journal Export Agrculture 32: 105-111.

Khurshid S. Ahmad I. Anjum MA. (2004) Genetic diversity in different morphological characteristics of litchi (Litchi chinensis.) 6:1062-1065.

Kumar R. (2013). Effect of vegetative flushing and shoot maturity on flowering, bearing behaviour and fruit yield in litchi (Litchi chinensis). Current Horticulture, 1(1): 30-34.

Kundu M. sagar R. (2014). Handbook Analysis and Quality Control fiJI' Fuits and vegetable products, Tata McGrail Hills Publishing Co, Ltd" New Delhi : 102-103.

Menzel CM. (2001). The physiology of growth and cropping in lychee. South African Litchi Growers' Association Yearbook, 12: 9-14.

Menzel CM. Rasmussen TS. Simpson DR.(1989). Effects of temperature and leaf water stress on growth and flowering of litchi (Litchi chinensis Sonn.). Journal of Horticultural Science, 64: 739-52.

Nacif SR, Paoli AAS. Salomao L. (2001). Morphological and anatomical development of the litchi fruit (Litchi chinensis Sonn. ) . Journal Horticulture Science. Fruits, 54: 225-333

Olesen TCM. Menzel N. Wiltshire CA. Conchie M. (2002). Flowering and shoot elongation of lychee in eastern Australia. Austral. J. Agr. Res. 53:977983.

Osborn ET. Valenzuela-RG. Muyrangel MD. Gardea-Bejer AA. and Villarreal RM. (2008). Sex expression and flower anatomy of litchi (Litchi chinensis Sonn.) .Revista Atotecnia Mexicana,31(1): 51-56.

Pathak S. Das SP Mitra SK and Dutta SK. (2013). Effect of temperature on growth and flowering of litchi (Litchi chinensis Sonn.) cultivars. Journal Horticulture Science 63: 347-358

Ram RB. Verma SK. Kumar A. and Kumar R. (2006). Studies on flowering behaviour, sex expression and fruit set in litchi (Litchi chinensis Sonn.) cultivars under Lucknow condition. Plant Archives, 6 (2): .673677. 
Rani A. (2006). Performance of litchi cultivars under tarai conditions of Uttaranchal. Thesis, M.Sc. G.B.P.U.A,T., Pantnagar, Uttarakhand, India : 99..

Robbertse H. FivazJaco C. Menzel C. (1995). A Reevaluation of Tree Model, Inflorescence Morphology, and Sex Ratio in Lychee (Litchi Chinensis Sonn.).J. Amer. Soc. Hort. Sci. 120:914920.

Sarkar S. and Bandyopadhyay A. (1989) Blossom bud differentiation and autogeny in litchi (Litchi chinensis Sonn.). Indian Journal of Horticulture, 31 (2): 148-153.

Sahay S. Hoda MN and Kumar N. (2005). Studies on sex ratio, fruit set and fruit drop of some litchi cultivars. Indian Journal of Horticulture, 62(1): 83-84.

Sharma SB. and Roy PK. (1987). Flowering and fruiting behaviour of some litchi cultivars. Haryana J.Hort.Sci.16:498

Singh AK. .Kumari R and Ray PK. (2010) Genetic divergence in litchi genotypes grown in Bihar. Environment and Ecology, 28:220-223.

Singh B. Chadha KL. and Sahai S. (2010). Performance of litchi cultivars for yield and physico chemical quality of fruits. Indian J.Hort.67:96-98.
Singh G. Nath V. Pandey SD. Ray PK. and Singh HS. (2012). Cultivars andgenetic enhancement. In: The litchi. Papademetriou, M. K. and Dent, F.J.(Ed.), Food and Agricultural Organization of the United Nations, New Delhi,India,: 18-24.

Sorkheh GK. Jain AST and Jinda RR. (2011). Studies on sex ratio, fruit set and fruit drop of some litchi cultivars. Indian Journal of Horticulture, 6s2(1): 83-84.

Stern RA. and Gazit S. (1996). Lychee pollination by the honeybee, J. Amer. Sco. Hort. Sci. 120: 152-157.

Stern RA. and Gazit S. (2003). The reproductive biology of the lychee. Hort. Rev. 28: 393-53.

Sukhvibul N. Dasananda M. and Vorapitiruangsri S. (2014). Growth, Flowering and Fruit Development of Lowland Litchi Cultivars. Acta Hort. 1024

Tindall, RD Stey JD and Kai RD .(1994). Effect of temperature on growth and flowering of litchi (Litchi chinensis Sonn.) cultivars. Journal Horticulture Science 63: 347-358

Vieira G, Finger FL. and Agnes EL. (1996). Growth and development of litchi fruit cv. Brewster. Bragantia, Campinas. 55 (2): 325-328.

\section{How to cite this article:}

Manish Kumar Jha. 2020. Study of Flower Morphology, Pollen Viability, Germination and their Effect on Fruit Set in Different Cultivars of Litchi. Int.J.Curr.Microbiol.App.Sci. 9(01): 1248-1259. doi: https://doi.org/10.20546/ijcmas.2020.901.138 